\title{
8 Bosnian women on hajj
}

\author{
Dženita Karić
}

The hajj features annually on Bosnian TV and is a frequent topic of religious radio-shows. Despite devastating war and post-war economic precarity, the number of Hajijis is increasing. The increased visibility of the hajj and Hajiis might seem to be a recent phenomenon and could be taken to demonstrate how Bosnian Muslims have 'rediscovered' their religion in the post-war period. However, I would argue that the big interest in the pilgrimage actually indicates continuity and persistence of religiosity that was perhaps less visible, but still alive among Bosnian Muslims throughout the 20th and 21st centuries. Hajj - a practice that was less available to majority of Muslims, and especially female believers in earlier times - was often described or discussed in various textual sources, which can tell us more about the complex relations between religion, visibility, and writing in socialist Bosnia in the second half of the 20th century.

In relation to this, the social value of the honorific title Hajii is as great as ever. Significantly, the local female variant of the title hadžinica now refers more to a female person who has performed her pilgrimage than just a marital status of being a wife to a Hajji as it was used in the past. ${ }^{1}$ Women's hajj travelogues are available online on different social media, including blogs. The visibility of younger and older female pilgrims and representations of their pilgrimage experiences are strongly present in printed media and online. As with any historical phenomenon of greater social relevance, it is tempting to assume that this kind of visibility existed throughout the 20th century as well.

This paper will deal with 'layered visibility' of female pilgrimage in the socialist context of Bosnia and Herzegovina. It will show how women's performance of pilgrimage is related to their bodily, discursive, narrative, and political visibility, and provoked reactions from different levels of authority: male and scholarly, societal and state-based. On the basis of close reading of several texts published between the 1960s and 1980s in several national Muslim journals such as Glasnik and Preporod, I want to point to ways in which the pilgrimage of women - whether as an object of theoretical debate or as a lived practice - reflected widespread social anxieties as well as individual believers' motivations. In particular, I will pay attention 
to the slowly increasing female perspectives on the hajj in textual sources, while having in mind that invisibility of female written traces does not equal women's absence from pilgrimage practice. On the contrary, while the visibility of female participation in pilgrimage can be retrieved from earlier available sources, the unmediated presence of women's perspectives on pilgrimage offers a more direct insight into how women experienced hajj in this particular period.

\section{Theoretical framework}

The last several decades have offered vibrant discussions - especially in the field of Islamic feminism - regarding the visibility of women in Islamic sources and the ways in which power and authority erase, stifle, or misinterpret female voices and agency. Recently, the focus of Islamic feminist works turned to explorations of the various ways that ethics in classical Islamic thought are gendered, and thus shaped by a hierarchical genealogy that did not favour women (Ayubi 2019). At the same time, numerous Muslim feminists have aimed to 'exhume a more woman-friendly version of history' (Afsaruddin 2010, 112), shifting the focus to possibilities of hermeneutics, especially in relation to foundational and early modern Islamic texts. As I aim to demonstrate here and as comes to the fore in the contribution to this volume by Jacqueline Fewkes, as a result of extensive anthropological and historical research on erasure and on the agency and voices of Muslim women, it transpires that visibility of women is almost a surpassed notion, especially when made a token and a tool of different ideological causes.

However, visibility itself is not a straightforward concept; it can contain multiple layers. ${ }^{2}$ Contemporary discussions on the topic of women in historical sources admit the difficulties, if not impossibility, of extracting female voices to produce more adequate insights into how women truly went through different life experiences. Apart from the fact that gaining a 'true insight' into the female experience of pilgrimage in the first-person narratives, for instance, might prove to be problematic because of genre constraints and narrative limitations, we are also faced with the near lack of such sources in the pre-modern period. A significant increase in first-person narratives, usually in the shape of travelogues or diaries, is inevitably connected to the modern era (roughly defined as mid-19th century onwards) as one of the results of simultaneous developments in technology and literacy. However, such a progressivist historical narrative does not account for local variations. In the case of Bosnian female hajj writing, the starting date is more than a century later. If the key element of the concept of visibility in sources is the appearance of women's own voices, then resistances to it as well as conditions that led to its emergence are left out. In contrast to this, our definition of visibility has to include instances of the presence of female pilgrimage in various sources, even in the case when these sources offer only pure theoretical speculations aimed at a male readership. The visibility 
of female pilgrims, in other words, has to be understood also as the discursive presence of female pilgrimage even when the narrative framework in which it appears is set up by male authors.

The visibility of female pilgrims has other connotations besides the discursive and textual. Women's bodily presence and various ways of their being bodily present in the texts range from abstract/ideal female performance of the hajj to their problematic bodily presence and women's own portrayals of the body-in-pilgrimage. As such, as I will demonstrate for Bosnian female pilgrims, their bodily visibility provoked responses from different levels of male authority. Observed in the particular context of socialist Yugoslav discouragement of religious practices, one might say that female pilgrimage assumed political visibility and thus functioned as a potential form of resistance to perceived oppression from the authorities. $^{3}$

Similar to the regulation of visibility of female pilgrimage, discussions about the mobility of women in itself refers to more than the 'freedom' to move, and is 'mediated by the relation between the individual and the collective dimension' (Bougleux 2016,13). More than other religious duties in Islam, such as prayer or almsgiving, the hajj bring the female body into the public sphere. Especially in the modern period starting from the mid-19th century, female (and male) movement became entangled in a wider set of relations that included new realities of borders, empires, and nation-states. Mobilities of bodies, similar to their visibility, are therefore not dependent exclusively on agency and freedom. However, as we will see later, both mobility and visibility can be used by women in unexpected ways.

Studying mobility and visibility we must reflect on a theoretical and analytical problem. The first one is primarily related to a discourse which assumes that visibility is by its nature a positive development: the idea that objects move from a position of being unknown to come into 'light' and gain recognition as subjects with implied agency. ${ }^{4}$ More problematic, however, is the question of mediation: who gets to present visibility, in this case of women, and who gets to interpret it?

These questions become more pertinent if we consider the previously mentioned lack of sources related to the mobility of women in the framework of authoritative Islamic texts. Since the first records of visibility of women on pilgrimage can be traced to sources written by male authors, one might be tempted to think that visibility of women was not regulated or controlled by women themselves, but that they simply 'emerge' into the history of pilgrimage at a certain point as male authors decided to insert them. I will demonstrate that, on the contrary, the visibility of female pilgrimage was not simply regulated by male authors or used to express societal anxieties but could also be claimed and disclaimed by women themselves. Invisibility, in other words, had a potential to subvert the existing relations of power and, through tactics of hiding or un-telling, gain more desired mobility. ${ }^{5}$ 
My account of hajj practices of Bosnian women in the socialist period will show the historical line of writing on pilgrimage of and by women: the ways and media in which women's pilgrimage was present and shifts that can be noted throughout the latter decades of the 20th century. Analytically, it points to pilgrimage as the ultimate type of mobility that provokes the ways we see invisibility of women in textual sources, public domain and private devotion.

\section{Female pilgrims and blind spots of historiography}

The history of female religiosity in the Yugoslav region and post-Second World War period remains largely understudied, representing a more general neglect of religiosity of non-elite members of Bosnian society. It is possible to argue that in terms of area studies, this neglect echoes a broader ignorance of pilgrimage of Muslim women in wider scholarship. To take only one example: the edited volume on pilgrimage of women in European context that came out in 2012 does not take into account Muslim pilgrimage at all, despite a huge interest in both the local ziyāra and hajj amongst indigenous Muslim populations in South-Eastern Europe and immigrant communities across Western Europe (cf. Jansen and Notermans 2012). However, recent initiatives dedicated to the exclusive research of hajj show a positive change in this regard, allocating place for the study of Muslim women in different contexts (cf. Mols and Buitelaar 2015).

The academic neglect of female religiosity in the Bosnian context may well be a direct result of the strong focus on state regulations of religiosity in the 20th century and reactions of the major Islamic institutions in the region, with little attention being paid to how people on the ground actually lived through these changes. The focus of local historiography has by and large been on the issue of female dress, especially how the socialist authorities banned the veil. This focus on the veil reflects a larger trend of scholarly neglect of other facets of female religiosity. ${ }^{6}$ Only recently has the focus shifted to the intricate connection between the religious life of Bosnian women, their commitment to Yugoslav patriotism, and their dedication to the idea of the umma (Rexhepi 2017). This shift in focus reflects a larger trend which aims to show how the Bosnian region remained closely connected to the rest of the Muslim world, even in the aftermath of the Second World War (Fichter 2017; Henig 2016; Miller 2016) and the end of the overt pan-Islamist aspirations and motivations (Aydin 2017). These new trends point to the necessity of overcoming the narrow focus on nation-state frameworks to study how transnational flows affected lives of common people. Moreover, recent scholarship has taken an interest in socialist ways of organizing women in the post-Second World War period, with all its complex relations to feminism and state power (Hadžiristić 2017; Funk 2014). 
As for hajj studies over the last few decades, it is possible to notice that the overwhelming focus is on male actors who contributed to the political and intellectual visibility of Muslims in Europe or other strategically important geographical nodes, and whose pilgrimages clearly illustrated the 'dialectical relationship between religious practice and Muslim nationalism, and between global and local Islamic politics' (Tsai 2017, 193). While not neglecting the importance of local-global dynamics and its effects in the 20th century, the pertinent questions arise: What happened to the mobilities of those who are less present in textual sources? What about their international connections and, more importantly, their shared sensibilities with other Muslims?

In this regard, the importance of studying Bosnian Muslim connections with the wider Muslim World after the demise of the Ottoman Empire is important for multiple reasons. On the most basic level, it shows how Bosnian Muslims retained their spiritual, educational or family links with coreligionists in Turkey and the Middle East. Despite state pressure on severing these links which affected the way Islam in which the region was stereotypically portrayed, ${ }^{7}$ even a cursory glance at the highly censored print of the post-Second World War period shows an ongoing interest in affairs and state of Muslims in other parts of the world. Connectivity persisted beyond the public sphere throughout the 20th century: for example through family links of $m u h a \bar{j} j i r^{8}$ communities with their country of descent. More visibly, the links with other parts of the Muslim world not only persisted but also developed in new directions with an increase in the number of Bosnian students in Cairo, Baghdad, Kuwait, and other cities as at least partly a result of the non-aligned movement. ${ }^{9}$

Researching Muslim connections can help in understanding how religious sentiments persisted among a great number of Bosnian Muslims throughout the second half of the 20th century. Their communication, correspondence, and interaction with other Muslims across the world, using shared religious discourses and reflecting on common feelings of perceived unity, bore a direct relation to their religious practices. Furthermore, while educational links of Bosnian Muslims with other parts of the Muslim world are also related to the privilege and prominence of certain actors and sections in society such as the ulama, the hajj offered an opportunity for larger numbers of other social groups to attain various forms of visibility during the performance of a religious ritual. The process, however, was not straightforward. State regulation of the hajj varied throughout the socialist period which lasted more than four decades. The politicization of hajj and its utilization for Yugoslav foreign policy fluctuated (Bećirović 2012, 406-410). The immediate post-Second World War period, for example, is characterized by a low number of Hajiis. ${ }^{10}$ The scant information available from the records shows that several women participated in the hajj between 1945 and 1950, with a slight rise in the years to come (Bećirović 2012, 410). 


\section{Dženita Karić}

Thus, although the state controlled hajj performance, as a result of which the number of pilgrims was significantly reduced, it did not completely cease in the first decades of the socialist rule. Since going on hajj in the second half of the 20th century depended on different factors that regulated who could travel and under what conditions, the visibility of women also varied. Still, as I will demonstrate below, more than other types of mobilities, the hajj had the potential to bring out an array of different concerns of and about women from the second half of the 20th century.

\section{Opposition to female mobility}

Historiographies of the post-Second World War period in Yugoslavia have mostly focused on top-down changes as a direct result of suppression of religious organizing and activities. In 1946, sharia courts were abolished, religious education was gradually suppressed until it was completely banned in 1952, and a ban on the full-face veil was enacted in $1950^{11}$ and on the Sufi orders in 1952. ${ }^{12}$ All these bans led to decreased visibility of Muslims, or at least of Islamic practices, in the public sphere.

However, while the visibility of Muslims was being suppressed by the state, another type of invisibilization was taking place in a different context a mere decade after the bans were enforced. While the public sphere was narrowing options for Muslim scholars and educators, some of the ulama were still active in the educational field. They shared their work in private correspondences, although in special cases - such as disagreements or debates - some of it reached the Glasnik (Herald), the official journal of the Supreme Islamic Authority in Yugoslavia. ${ }^{13}$ One of the issues that provoked a debate in the early 1960s was the question of women's hajj performance. The debate was between two Islam scholars who presented two polarizing attitudes concerning the issue of female mobility. Derviš efendija Spahić (1893-1978) was one of them. Being traditionally educated through the Islamic school or madrasa system in Bosnia, in 1934 he established a school himself and was acting as its sole teacher (Mekić 2017, 150). Having returned from his pilgrimage in 1962, he wrote a treatise about women and their participation in hajj. He concluded the following:

During my hajj journey, I noticed that the presence of women in the Holy places and their hajj practice contradict Islamic prescriptions. After returning from hajj I took an interest and wanted to know which conditions have to be fulfilled so that women can go on hajj (and fulfil the duty) themselves.

(Šošić 2015, 221) [my translation, DK] ${ }^{14}$

The major point of contestation of the author regarding the performance of female pilgrimage was the issue of clothing and seclusion. Spahić tried to prove his point with a discussion of sources. His main arguments were 
derived from a specific reading of a hadith taken from the al-Bukhari collection which emphasized that women should perform pilgrimage rites at night, when they could not be seen by men or interact with them. While explaining the context of the prophetic injunctions, Spahic contrasted them to modern times where, according to him, certain conditions were not met. He specifically listed four situations in which women's hajj performance produces more damage than good: they cannot be covered decently there, which is why they should avoid such situations; they cannot guard their eyes during travel, and guardianship of the gaze is a duty for both men and women; they must not come in contact with men, which is unavoidable during such a journey; and they corrupt the prayer for men if they mix with them during the ritual. He concluded by saying that one woman can corrupt a prayer for three men (Šošić 2015, 224-225).

Spahić's strong reaction to female mobility and the increased visibility of women, particularly their exposure to the male gaze, is surprising if we take into account that the number of women who went on hajj was small anyway. So what could trigger his response in such a way to express general intense dissatisfaction with the idea of women going on hajj? I surmise that the answer lies in Spahićs preoccupation with clothing and visibility during the hajj, emphasizing that he did not consider modern conditions of travel suitable enough for the desired invisibility of women during pilgrimage. The imperative of invisibility, thus, overtakes the necessity of religious duty in his view. I would argue that Spahićs focus on the corrupting visibility of women may well reflect insecurities produced by sharp transformations in socialist Yugoslavia. The specific period in which Spahić wrote his critique of female mobility did not offer much to men of religion in terms of power and authority in the public sphere. His extraordinary criticism of female religious mobility can therefore be interpreted as a symptom of diminished male dominance, affecting, in turn, conceptions of masculinity in socialist realities. ${ }^{15}$

The treatise produced a sharp rejoinder by another Muslim scholar, Hasan Ljevaković (1913-1986), whose response was published in the same journal, together with Derviš Spahić's protest. While trying to refute Spahić's claims, Ljevaković used an array of Islamic sources such as the Qur'an, hadiths and opinions of classical fiqh scholars. The same sources were used by Spahić, but the two authors interpreted them differently: Spahić found arguments in them to limit the mobility of women, while Ljevaković complied with the majority opinion in favour of women going on hajj (Ljevaković 1969, 454). In his answer, however, Ljevakovićs also referred to local religious authorities by saying that 'none of the ulama in Yugoslavia (...) tried to prevent Muslim women from going on a hajj' (Ljevaković 1969, 454). Female mobility as such is the focus of his response, and going on hajj is subsumed under the general rubric of travel. Ljevaković continues by differentiating between different types of female mobility in the modern world. According to him, the hajj is a strict religious obligation and women 


\section{Dženita Karić}

should not be prevented from performing it. However, he emphasizes unspecified other travels that Muslim women engage in, pointing out how they behave 'unislamically' by going where they should not be going, using various ways of transportation and mixing with men. Ljevaković adds that neither he nor Spahić had ever publicly criticized that type of travel (Ljevaković 1969, 454).

What appears to be underlying the issue of female pilgrimage journey here is the question of authority: Who can speak for Muslim women and who can authorize their mobility? In the course of their debate, both Spahić and Ljevaković tried to define authority and find a textual precedent for their own respective opinions. At the same time, they felt the anxieties of the age: Spahic because his vision of Islamic social ethics was endangered by socialist and secular modernity. For him, the mobility of women was directly related to their unlawful visibility, which in his view affects men in two ways: it is sexually disruptive and it challenges their masculine status in the public sphere. Ljevaković, however, stressed the need to differentiate between different types of female mobility, of which some, like hajj, are religious obligations and women's religious right, whereas others are opening ways to unlawful behaviour and mixing with men. What Ljevaković stressed, however, is the general silence of Muslim ulama regarding the latter, which might be connected to the loss of their authority in the public sphere.

Regardless of the outcome of this debate, women were going on hajj in increasing numbers, evidenced through the annual Hajii lists in Glasnik and as a result of changes in transport and general loosening of the state grip on the regulation of religious practices. Articles published in Glasnik also urge potential pilgrims - men and women alike - to go on hajj if they fulfil the necessary requirements instead of sending a replacement (bedel). ${ }^{16}$ While debates such as the one between Spahić and Ljevaković no longer appeared, haji pilgrimage in general and female pilgrimage specifically came under scrutiny for potential accompanying dangers it might entail. The fact that women were moving was not disturbing in itself; it was their increased visibility and new ways of socializing during the travel (mixing with men on new means of transportation) that particularly frightened the ulama. If the two perspectives given by Spahić and Ljevaković are observed in parallel, we can see that the religious urgency of the hajj obligation is valued differently. However, what both authors have in common is the underlying juxtaposition of mobility and visibility, on the one hand, and the connection of hajj with other types of travel, most notably travel for leisure, on the other hand. The next section will deal with negative assumptions of Muslim journalists and readership towards variants of female hajj performance which was perceived as coming dangerously close to tourism. As in this section, the problematic juxtaposition is directly related to undesired forms of female visibility. 


\section{Pilgrimage, tourism, or something else}

In 1972, some readers of the newly established biweekly journal Preporod (Revival) ${ }^{17}$ were embroiled in a heated discussion about an article that had recently appeared in a Belgrade journal. The journal had published an interview with Vahida, a young Bosnian Muslim woman, who owned a discotheque and was married to an Orthodox Christian. Those two things were already controversial for a Bosnian audience, but specifically the fact that the interview revolved around the recent hajj experience of Vahida stirred strong emotions. According to the rendering of the interview, she claimed to have gone on hajj for touristic reasons, on a road trip to see the countries of cultural significance to the Muslim tradition. During the hajj performance, she was allegedly attacked for being white and different from other pilgrims. The photograph that was taken to accompany the interview showed her in a miniskirt.

The reactions to the interview came from several readers of Preporod, including a letter from Vahida's father, who was an imam (other letters alluded to her connection to the imam as well). While other letters questioned her motivations for performing the pilgrimage (Kadić 1972, 6), her father tried to elicit her response to the attacks. He claimed that her behaviour, as he had heard, was in line with what is expected of a pilgrim; she had helped other pilgrims and had performed the rites as stipulated. What the strong reaction of readership to Vahida's hajj experience showed is how she did not fit the standard image of a Hajia because of her clothes and behaviour as well as her exposure in the Serbian media (the newspapers did claim that Vahida does not bother about 'religious customs'). This also implied strong suspicion as to her travelling motive: if it was tourism, then it brought her hajj performance into question. Her behaviour as a tourist, in other words, would imply that she was an ignorant pilgrim at best, and a traveller who looks for sensation at worst.

Vahida's perceived touristic behaviour was deemed even worse by the Preporod readership because her experiences were published in a sensationalist journal, thus not only demeaning the hajj, but also exposing her to unregulated gaze of unknown and hostile readership. As for her Belgrade readership, her own specific personal history of being both an insider to the Muslim community in terms of her origin and upbringing and outsider to it by her marriage and lifestyle placed her in a position to be exposed to the outsiders. This sensationalism ascribed to hajj has deeper connections with an Orientalist view of the female body as an object that is simultaneously hidden from the view, but with the ability to entice foreign male gaze. In this context, the response of the Preporod readership can be interpreted as a reaction to the intruding gaze and a desire to limit the unwanted visibility, ${ }^{18}$ as well as the implication that such provocations harm the religious freedom of Muslims in socialist Yugoslavia (Tokmaković 1972, 6). 
This is why the polemics about Vahida's pilgrimage is doubly important: it reveals conflicting discourses inscribed on the visible female body, and it also points to the perceived limits of her religious mobility. In contrast to Spahić-Ljevaković debate, which revolved around the issue of absolute visibility of women during hajj, debates in the journal from the 1970s onwards do not question the visibility of women during hajj in itself, but the manner and representation of that mobility. However, similar to the earlier debate, female mobility and consequently women's visibility exacerbated already existing societal anxieties. Controversies surrounding atypical female mobilities as well as Orientalizing discourses that reduced female religiosity to a set of exoticized stereotype still did not stifle the expression of hajj experience by women themselves. The following section will present what women themselves wrote about hajj and how they negotiated visibility on their own terms.

\section{Kaleidoscopes of female piety}

While the second half of the 20th century witnessed a huge increase in the number of female pilgrims across the world, including in socialist Bosnia, the sources for investigating women's personal impressions remain limited to a few occasional travelogues and memoirs, thus constraining the scope and depth of the research that can be undertaken regarding female experiences of pilgrimage. Moreover, the existing research that deals with female hajj travelogues often stops with those that depict pilgrimage of prominent, elite women or European converts (Sayeed 2016; Mahallati 2011). A focus on oral accounts on hajj is another extreme (Cooper 1999). What we need, in addition to the existing research, is to focus on the textual production of non-elite women. For Bosnian female pilgrims, new developments in the printing enterprise offered new possibilities to publish their stories, enhancing their visibility as female pilgrims as well as giving them the opportunity to control their personal pilgrimage narrative. On a wider scale, the study of self-narratives or ego-documents of 'ordinary' people provides space for researchers to gain insight into how non-privileged and socially less prominent pilgrims experienced the ritual and the journey, thus heeding Abdellah Hammoudi's call for the research of hajj of 'men and women actually undertaking pilgrimage' and not just of writings by Muslim elites (Hammoudi 2009, 51).

Despite an overwhelming emphasis on male hajj pilgrimage, in the course of 1970s and 1980s Bosnian women who went on hajj or used the motive of the pilgrimage in devotional expressions were visible on the pages of the previously mentioned journals Glasnik and Preporod. This visibility increased as transport and liberalization of travel policy in Yugoslavia improved, enabling women to express their relationship to the hajj, Mecca, and Medina in a variety of original ways. 
In this sense, print in the several decades of socialist rule enhanced not only the stereotypes about Muslim women, but also gave women the opportunity to describe their own experiences and share them with a wider audience. While print opened new gateways for depictions of hajj, it also provided a wider framework for the discussion of various issues related to Muslim women. In the case of Preporod, a rather straightforward approach allowed readers and authors to discuss issues such as women's lack of access to mosques (Preporod 1 May 1972), the necessity of female emancipation through education (Preporod 15 October 1974), historical perspectives on female participation in public life (Preporod 1 April 1974), Islam and female education (Preporod 15 December 1972), and the need for the print media to speak directly to women who are a significant part of the readership (Preporod 1 November 1974).

While it is difficult to ascertain the full scope of female religious writing, it is evident that some of it was reserved for close family circles, and that hajj travel accounts reached wider audiences only rarely. ${ }^{19}$ However, expressing religious experience was not limited to travelogues and travel literature in general. What follows next are examples of several modes of expression of devotion to the pilgrimage and hajj related practices among Bosnian women.

Female presence in dominantly male journalistic spaces was marked in a range of ways. In its early period the biweekly newspaper Preporod contained a section devoted to questions related to women and family. The section was devoted to didactic essays regarding sexual ethics, but also to questions related to domesticity, such as food and fashion. However, the section disappeared after the first several issues, to the dismay of some of its readers. There is a steady presence of women in hajj travelogues written by men, which were published in newspapers and journals in a serialized form and sometimes reprinted as books (Ljubunčić 1955; 1950). Women were listed as fellow travellers, often by name which indicated a level of familiarity. In the context of journalistic coverage of the pilgrimage, women often featured in hajj experiences of men, but not necessarily as pilgrims. In 1971, Devlethanuma Ćatić sent a notice to Preporod in which she wished her son and his friend a happy journey (Preporod 1 January 1971, no 8). In another place, a 12-year-old girl, Aida Omerbegović, wrote a short impression of a farewell ceremony she attended with her grandfather, emphasizing that while she did not know much about the hajj beforehand, the ceremony itself instilled various emotions in her (Preporod 1 May 1972). Sometimes women did not leave any written trace of their religious experience, but their unique devotional practices were nonetheless reflected in the pages of the journal. In 1973, two older women were mentioned in relation to that year's hajj: one was mentioned as having paid the costs of the hajj journey for the other, which was applauded by Preporod as an act of piety which was socially beneficial (Preporod 15 December 1973). 
Travelogue writing on the pages of Preporod was not reserved for hajj travels only. The newspapers offered ample space for reports about different kinds of journeys, mostly related to official visits to other Muslim communities in the Middle East and Russia. As for female travel writing, several travelogues appeared written by younger women who described their touristic visits to the Middle East and North Africa. The appearance of the first hajj travelogues in Bosnian print thus does not seem to be an aberration or an exception. The first hajj travelogue written by a woman appeared in 1970 in the official gazette Glasnik, and was written by Razija Hegić. The travelogue was quite short and described the hajj itinerary and Hegić's personal impressions of the ritual (Hegić 1970, 305-308). The travelogue was also edited and prefaced by the journal, with a short remark which emphasized the necessity for hajj reportages or travelogues to be original and interesting. Razija Hegić went on hajj two years prior to sending her travelogue to the journal and the editors commented heavily on the content of her travelogue. The themes that Hegić addressed in her travelogue revolved around the common topics of devotion and amazement at the diversity of Muslims encountered during the hajj.

The author herself appeared several times in the journal Glasnik (Mekić 2017, 145), suggesting that readers felt the need to engage with different topics related to their religiosity. In that context, Razija Hegić also appeared as one of the people sending questions to Husein Đozo (1912-1982), a prominent Bosnian 'älim (Muslim scholar) from the socialist period, asking him for a fatwa. On this occasion, she sent a question about permissibility of praying with nail polish. This detail illustrates a transformation of the form and use of fatwa in the socialist Yugoslavia. By identifying themselves as fatwa seekers, women entered the public sphere to ask for interpretations of questions related to their own daily religious practices. Besides presenting themselves as seekers of religious interpretations, religiously educated women also started to offer interpretations of rules related to female performance of hajj. In 1983, Subhija Skenderović published an article on the religious rules and practices regarding hajj of women. That Islamska misao thought it wise to pay attention to these regulations indicates that a rising number of women went on hajj towards the end of the socialist period (Skenderović 1983, 28-30).

Still, the number of contributions by women in journals was significantly lower than that of their male coreligionists. A special issue dedicated to hajj, which was published in the journal Islamska misao (Islamic Thought ${ }^{20}$ in 1980, showed no contributions by female authors, although they clearly existed (Fajić 1980, 21-22). Thus, what appears from this negligence of women's writings on hajj in male-authored surveys and bibliographies is another invisibilization of female pilgrimage experience, whether as a result of ignorance or disregard for their production. However, as the next and final section of this paper will show, women had their own unique ways to negotiate visibility of their writing and, even more importantly, their hajj. 


\section{Driving all the way to Mecca}

During the summer of 2014, family members of a Sarajevan housewife, the late Hidajeta Mirojević, published her hajj diary. They circulated the copies only amongst trusted members of family and friends. Although their mother and grandmother had died some time ago, they wanted to share her hajj experience and show its uniqueness to a Bosnian readership. The introduction to the travelogue was written by Hidajeta's close friend and hajj companion Safija Šiljak. The main part of the travelogue was written by Hidajeta, but her children interpolated the text with shorter and longer comments with information on various mosques or places of religious significance. These interpolations seem to permeate female hajj travelogues, revealing the perceived need for clarification. The information was taken from different webpages, including an online travelogue published earlier. ${ }^{21}$ Photographs of Hidajeta and Safija were also added, as were their driving licences and scans of letters sent to Hidajeta by her children. All this material can be interpreted to serve multiple purposes: while it documents Hidajeta's journey in detail and confirms her itinerary, the information is also supposed to guide future pilgrims, a common motive in hajj travelogues.

What emerges from this is a snippet of Hidajeta's life. As a young girl during the Second World War she helped Bosnian refugees who had escaped the horrors in Eastern Bosnia. After the war, she got married, became a housewife who raised her children and went on holidays to different places outside Yugoslavia with her husband. Her friend and hajj companion Safija suffered a more turbulent fate. After the Second World War, she was imprisoned for more than two years for her political activism stemming from her involvement with the Bosnian Young Muslims organization. This reformist Islamic organization that was founded in 1939 was suppressed several times throughout the 20th century. Because of Safija's membership and activism, and subsequent imprisonment by the socialist authorities, she suffered being socially ostracized for at least several years. In the early 1980s, she was working as an accountant for Energoinvest, an energy company which was at the time a symbol of socialist industrialist progress.

In 1981, Hidajeta and Safija decided to go on hajj by car, and since their husbands were unable to drive, they undertook the task themselves. For Hidajeta, travelling by car seemed cheaper, but Safija also had a more urgent reason. Because of her political past, and in order not to upset her employers, Safija preferred to plan her hajj journey outside the control of the Islamic Community of the SFRY that regulated the number of pilgrims and way of transport. The historical climate at the time was tense; socialist authorities were alert because of the potential effect of the Iranian Revolution, which eventually ended in a widely publicized trial of Bosniak intellectuals in $1983 .{ }^{22}$ 
An important factor in realizing the hajj journey was the use of international driving license, especially since it allowed Hidajeta and Safija to drive through the Kingdom of Saudi Arabia. The travelogue shows photos of both Safija and Hidajeta's licences as well as their photo in front of the small car. From the travelogue it transpires that their driving all the way through the Hijaz could have been interpreted as curiosity at the time of their hajj journey; it certainly inspired amazement when the travelogue of the Hidajeta's appeared in 2014, when comparisons to contemporary status of women who want to drive in Saudi Arabia elicited near disbelief.

In any case, Hidajeta and Safija imagined the hajj as a wholesome project which also included seeing numerous places of Islamic culture apart from performance of the rites. Embarking on such a journey by car instead of plane or a bus offered more opportunities for combining different travellers' motives, and went against the predominant dynamics of hajj journey in the age of jet travel. Safija and Hidajeta, for instance, also visited Bosnian friends who had migrated earlier and now lived in Istanbul. Here, the importance of female friendships across borders becomes visible. The maintenance of female connections across the Middle East is part of a wider connectivity of Balkan Muslims with mubajij communities. In an emotional passage, Hidajeta describes Bosnian muhäjirs she and Safija met in Bursa who wanted to talk to them as being moved to tears and treating them as their relatives. The hajj was also the opportunity for Hidajeta and her companion to meet Bosnians who live in other parts of the world, such as the USA. About the differential treatment of the American Hajiis, Hidajeta commented: 'They [the Saudi authorities, DK] treat them like gentlemen, because they have an American passport'.

Hidajeta stresses in her travelogue that solidarity was not reserved only for people of Bosnian or Yugoslav origin. In line with the inner dynamics of the travelogue genre, there was a visible tendency not only to present others, but to see how oneself is represented. While elsewhere the Yugoslavian identity was not particularly stressed, while meeting other Muslims Hidajeta stresses that other Hajjis were amazed when meeting Yugoslav fellow pilgrims.

What comes to the fore in Hidajeta's hajj travelogue is that her experience was inextricably bound to her impressions of the wider umma and its rich variety, which she was probably witnessing for the first time in her life. However, her travelogue also gives an intimate portrayal of her own emotional experience of hajj:

We slept outside, got into our sleeping bags and thus spent our first night in the desert. It is a special experience, the sky is full of stars and is close, the desert makes you think only of Allah, and I had a feeling that the whole duny $\bar{a}^{23}$ was left behind us, and that I am here with my life account in front of Allah. I could not sleep for a long time and that is when I realized the purpose of hajj.

(Mirojević, 39) 
For Hidajeta and many of her coreligionists, the hajj had a dual purpose: unity with 'brethren and sisters in faith' 24 and purification of all sins should one's pilgrimage be complete and accepted by God. In that sense, for Hidajeta hajj performance was not just about acquiring spiritual capital, but, in adopting the words of Cooper, 'a powerful and broadly held metaphor for both the individual spiritual quest and the collective emulation of an ideal Islamic community' (Cooper 1999, 93).

The story of the hajj experiences of Hidajeta and Safija sheds light on what Tanja Petrović describes as 'ordinary people' responding to control and regulation by the socialist Yugoslav and Saudi state and how they 'acted politically within the realm of social participation' (Petrović 2016, 509). However, what I would like to stress here is the interplay of different invisibilities which allowed Hidajeta and Safija to undertake the journey of their lifetime. Safija knew that her visibility as a pilgrim might have unwanted consequences when it came to her work, so she readily accepted Hidajeta's offer to use the car as a less noticeable means of transport. On the way to Mecca, however, precisely this type of travel put them into the spotlight of Saudi authorities, and they became visible in a way that presented them as an object of curiosity, but not endangering them. Finally, their authorial visibility was negotiated as well: the hajj diary was not published soon after the pilgrimage, when it might have raised the suspicion of the socialist authorities and put them in a predicament, but several decades later, under radically different historical conditions.

\section{Conclusion}

The visibility of women's hajj performance in Bosnian media today is present and uncontroversial - at least when it comes to women whose mobility is secured by having a mahram or male guardian who accompanies her on the journey. The mobility of a large number of women who do not have a mahram is contested and a subject matter of frequent questions posed to religious authorities. Once again, the religious mobility of women is a matter of scholarly explanations and regulations.

This article dealt with visibility of pilgrimage of Bosnian Muslim women over the course of several decades of the socialist rule (1960s-1980s). As a term with a variety of meanings and applications, the visibility of Bosnian women ranged from narrative and textual and bodily to political. I have demonstrated that the visibility of women in pilgrimage progressed over time: while it was a matter of debate among scholars in 1960s, without much say from concrete female pilgrims, it transformed into a reflection of different social anxieties in the 1970s to reach women's own expressions in the 1980s.

What the historical developments of female pilgrimage in this time period show is how visibility - and our understanding of it - depends on the availability of sources. The imperative of revealing a 'woman-friendly version of history' has to reckon with a lack of sources authored by women 
even in the 20th century. The invisibility of women should not be interpreted as meaning that they are passive. As I have demonstrated, close reading of debates penned by men reveals an ongoing anxiety with female mobility not only in relation to hajj, but also travelling options that were not available for previous generations. The later sources show a similar agitation, but this time directed at the manner in which a female pilgrim should be visible - and how she should not be. As time progressed, the appearance of female travelogues and notices on the pilgrimage shifted and enlarged the visibility of women, while at the same time raising questions related to the nature of visibility.

It is through the examination of female writings about hajj that we can observe how both visibility and invisibility play a part in understanding women's mobility. Hidajeta and Safija's hajj narratives present to us with a telling case study of this multifaceted regulations and negotiations of invisibility to avoid state or societal pressures. These women's choice to be visible as narrators at their own time and pace also shows us how, as for most pilgrims, hajj as a spiritual journey and a religious duty is a pivotal moment in their lives as believers.

\section{Notes}

1 That hajj gives a certain visibility in the shape of title conferred to women by husband's status of a Haiji is not an exclusive Bosnian occurrence; see Cooper (1999).

2 The image of visibility as layered has been noted in some earlier studies on the presence of women in historical sources. For example, in her article on women's presence in clothing industry in the US in the late 19th/early 20th centuries, Margaret Walsh analyses layers of visibility of women in labour force; see Walsh 2010.

3 In his recent article, Piro Rexhepi points to the value of writings such as hajj travelogues in their capacity to show the transnational links of Balkan Muslims with other parts of the Muslim World as well as undermining the notion of the isolated 'Balkan Islam'.

4 The emancipatory and liberating aura of visibility was problematized in a short article by Ilya Parkins and Eva Karpinski; see Parkins and Karpinski (2014).

5 The tactics of un-telling can also be related to the oral media in which female experience of hajj was conveyed before widespread literacy and access to printed media took over.

6 Although much has changed since Laura Deeb's assessment of the field in 2006, the heavy focus on the issues of veil and female clothing is still predominant in research of gender and piety in Bosnia. In many ways, it seems that Tone Bringa's valuable study from 1995 still remains unsurpassed regarding the study of Bosnian women's everyday lives.

7 In most studies on Islam in Bosnia in the 20th century, persistent links of Bosnian Muslims with their non-Bosnian coreligionists is overlooked or underplayed.

8 The term muhäjir refers to Muslim refugees and their descendants who moved from the Balkans in several waves: after the Austro-Hungarian occupation of Bosnia in 1878, Balkan wars (1912-1913) and during different social and economic crises of the 20th century. The muhäjirs settled not only in modern-day Turkey, but also across wider Middle East and northern Africa. Their descendants can be found in Syria, Palestine, and Jordan as well as in Tunis, Algeria, and elsewhere. 
9 The numbers are not easy to ascertain since there has not been a systematic study of the question yet.

10 In 1953, for example, only one pilgrim - a woman - went on a hajj.

11 As documented by various historians, the ban caused deep trauma amongst many Bosnian Muslim women, up to the point that some were not willing to leave their houses afterwards; more on the ban and how it affected women in Milišić (1999).

12 Different Sufi orders were active in Bosnia before the ban. The only existing detailed survey of these orders is brought by Ćehajić (1986).

13 The Supreme Islamic Authority was one of the organs of the Islamic Community, an institution established in 1882 to regulate matters related to Muslim believers in Bosnia (although in different historical periods, such as socialism, the authority of the institution spread over whole Yugoslavia). Glasnik was its official journal from 1933, and it is still being published, although its continuity was interrupted several times throughout the 20th century because of the wars.

14 Original text: Prilikom mog putovanja na hadž zapazio sam da je prisustvo žena na svetim mjestima $i$ njihovo obavljanje hadža u suprotnosti sa islamskim propisima. Po povratku sa hadža sam se zainteresirao $i$ želio saznati pod kakvim su uslovima žene zadužene da sobom obave hadž.

15 Regulation of women in situations of perceived endangered masculinity has recently been explored in the domain of Islamic ethics by Zahra Ayubi.

16 See Sokolović (1971).

17 Official biweekly journal of the Islamic Community.

18 The figure of the insider-outsider is frequent in contemporary Orientalist literature. The perceived liminality of this figure and its ability to 'reveal' and 'expose' Muslim realities explains the popularity of first-person narratives of (ex-)Muslim women such as Ayaan Hirsi Ali, Irshad Manji, and others.

19 This was not reserved only for female writing about hajj. During the course of my research, I have encountered certain difficulties in obtaining travelogues written by men for close family circles as well.

20 The journal was established in 1979 by the Council of the Islamic Community with the aim to provide more information regarding Islamic studies, theology and general religious knowledge.

21 On Bosniak online travelogues written after the war 1992-1995, see Karić (2018).

22 In 1983, the authorities tried and indicted several Bosniak intellectuals, including the first Bosnian president Alija Izetbegović, on the charge of Islamic fundamentalism. The Sarajevo Process, as it was called, caused a deep trauma to Muslims who sought wider freedoms of expression in the 1980s.

23 This world, as opposed to äkhira, or the Next World.

24 Hidajeta uses the expression bratstvo i jedinstvo 'brotherhood and unity' which was a common slogan during the socialist times, but gives it a twist by making it refer to the umma.

\section{References}

Afsaruddin, Asma. 2010. 'Literature, Scholarship, and Piety: Negotiating Gender and Authority in the Medieval Muslim World.' Religion \& Literature 42 (1/2): 111-131.

Aydin, Cemil. 2017. The Idea of the Muslim World: A Global Intellectual History. Cambridge, MA: Harvard University Press.

Ayubi, Zahra. 2019. Gendered Morality: Classical Islamic Ethics of the Self, Family, and Society. New York: Columbia University Press.

Bećirović, Denis. 2012. Islamska zajednica u Bosni i Hercegovini za vrijeme avnojevske Jugoslavije: (1945-1953). Zagreb: Bošnjačka Nacionalna Zajednica. 


\section{Dženita Karić}

Bougleux, Elena. 2016. 'Im/mobilities in Subjects and Systems.' In Bounded Mobilities: Ethnographic Perspectives on Social Hierarchies and Global Inequalities, edited by Miriam Gutekunst, Andreas Hackl, Sabina Leoncini, Julia Sophia Schwarz and Irene Götz, 13-16. Bielefeld: Transcript Verlag.

Bringa, Tone. 1995. Being Muslim the Bosnian Way: Identity and Community in a Central Bosnian Village. Princeton, NJ: Princeton University Press.

Ćehajić, Džemal. 1986. Derviški redovi u jugoslovenskim zemljama sa posebnim osvrtom na Bosnu i Hercegovinu. Sarajevo: Orijentalni Institut u Sarajevu.

Cooper, Barbera. 1999. 'The Strength in the Song: Muslim Personhood, Audible Capital, and Hausa Women's Performance of the Hajj.' Social Text 17 (3): 87-109.

Deeb, Laura. 2006. An Enchanted Modern: Gender and Public Piety in Shi'i Lebanon. Princeton, NJ: Princeton University Press.

Fajić, Zejnil. 1980. 'Bibliografija radova o hadžu objavljenih u Glasniku VIS-a od 1933. do 1980.' Islamska misao II (24): 21-22.

Fichter, Andrea Madigan. 2017. 'Student Activists and Yugoslavia's Islamic Revival: Sarajevo, 1970-1975.' In Dropping out of Socialism: The Creation of Alternative Spheres in the Soviet Bloc, edited by Juliane Fürst and Josie McLellan, 85-104. Lanham: Lexington Books.

Funk, Nanette. 2014. 'A very Tangled Knot: Official State Socialist Women's Organizations, Women's Agency and Feminism in Eastern European State Socialism.' European Journal of Women's Studies 21 (4): 344-360.

Hadžiristić, Tea. 2017. 'Unveiling Muslim Women in Socialist Yugoslavia: the Body between Socialism, Secularism, and Colonialism.' Religion and Gender 2 (7): 184-203.

Hammoudi, Abdellah. 2009. 'Textualism and Anthropology: On the Ethnographic Encounter, Or an Experience in the Hajj.' In Being There: The Fieldwork Encounter and the Making of Truth, edited by John Borneman and Abdellah Hammoudi, 25-54. Berkeley/Los Angeles/London: University of California Press.

Hegić, Razija. 1970. 'Utisci sa puta na hadž.' Glasnik: 305-308.

Henig, David. 2016. 'Crossing the Bosphorus: Connected Histories of "Other" Muslims in the Post-Imperial Borderlands of Southeast Europe.' Comparative Studies in Society and History 58 (4): 908-934.

Jansen, Willy and Catrien Notermans, eds. 2012. Gender, Nation and Religion in European Pilgrimage. Farnham: Ashgate.

Kadić, Vejsil. 1972. 'Gospodinu Hadži Husein ef. Đozi, uredniku "Preporoda” Sarajevo.' Preporod III (38), 1 (April): 6.

Karić, Dženita. 2018. 'Online Bosniak Hajj Narratives.' In Muslim Pilgrimage in Europe, edited by Ingvild Flaskerud and Richard Natvig, 58-69. Abingdon on Thames: Routledge.

Ljevaković, Hasan. 1969. 'Odgovor Hasan ef. Ljevakovića.' Glasnik vrhovnog islamskog starješinstva, XXXII (no. 9-10, Sept-Oct), 454-455.

Ljubunčić, Hasan. 1955-1956. 'Istorija hadža u Bosni i Hercegovini sa putem na hadž u 1954. godini.' Glasnik VIS-a. XIX: 1-2/1955: 42-55; 3-4/1955: 112-134; 5-7/1955: 174-184; 8-10/1955: 296-305; 1-3/1956: 62-88.

- 1950-1953. 'Put na hadž.' Glasnik VIS-a, (XIII), 4-7/1950: 130-136; 11-12/1950: 341-345; II (XIV), 1-3/1951: 51-54, 4-6/1951: 172-176, 7-9/1951: 
295-298, 10-12/1951: 389-392; III (XV), 1-4/1952: 68-73; 5-7/1952: 157166; 8-12/1952: 162-272; IV (XVI), 1-4/1953: 40-51, 5-7/1953: 152-161.

Mahallati, Amineh. 2011. 'Women as Pilgrims: Memoirs of Iranian Women Travelers to Mecca.' Iranian Studies 44 (6): 831-849.

Mekić, Sejad. 2017. A Muslim Reformist in Communist Yugoslavia: The Life and Thought of Husein Đozo. Abingdon on Thames: Routledge.

Milišić, Senija. 1999. 'O pitanju emancipacije muslimanske žene u Bosni i Hercegovini.' Prilozi 28: 225-241.

Miller, Brenna. 2016. 'Faith and Nation: Politicians, Intellectuals, and the Official Recognition of a Muslim Nation in Tito's Yugoslavia.' In Beyond Mosque, Church, and State: Alternative Narratives of the Nation in the Balkans, edited by Theodora Dragostinova and Yana Hashamova, 129-150. Budapest/New York: Central European University Press.

Mols, Luitgard and Marjo Buitelaar. 2015. Haji: Global Interactions through Pilgrimage. Leiden: Dutch National Museum of Ethnology.

Parkins, Ilya and Eva Karpinski. 2014. 'In/Visibility: Absences/Presence in Feminist Theorizing: Introduction: In/Visibility in/of Feminist Theory.' Atlantis 36 (2): 3-7.

Petrović, Tanja. 2016. 'Towards an Affective History of Yugoslavia.' Filozofija i društvo XXVII (3): 504-520.

Preporod. 1971-1974.

Rexhepi, Piro. 2017. 'Unmapping Islam in Eastern Europe: Periodization and Muslim Subjectivities in the Balkans.' In Eastern Europe Unmapped: Beyond Borders and Peripheries, edited by Irene Kacandes and Yuliya Komska, 53-78. New York: Berghahn Books.

Sayeed, Asma. 2016. 'Women and the Hajj.' In The Haji: Pilgrimage in Islam, edited by Eric Tagliacozzo and Shawkat Toorawa, 65-84. New York: Cambridge University Press.

Skenderović, Subhija. 1983. 'Žena i hadž - propisi i praksa.' Islamska misao V 56: 28-30.

Sokolović, Sinanuddin. 1971. 'Hadž: Jedna od pet osnovnih islamskih dužnosti.' Glasnik vrhovnog islamskog starješinstva XXXIV 11-12: 565-575.

Šošić, Dževdet. 2015. Islamska pedagoška misao i praksa Derviš-ef. Spahića. Travnik: ElčI Ibrahim-pašina medresa.

Tetarić, Ragib. 'Odlomci iz pisma hafiza Ragiba Tetarića.' Preporod, III, no. 38, 1. April: 6.

Tokmaković, Hilmija. 1972. 'Kako beogradske 'Večernje Novosti' serviraju neistine.' Preporod, III, no. 38, 1. April: 6.

Tsai, Yuan-lin. 2017. 'Pilgrimage and Hui Muslim Identity in the Republican Era.' In Religion and Nationalism in Chinese Societies, edited by Cheng-tian Kuo, 179-196. Amsterdam: Amsterdam University Press.

Walsh, Margaret. 2010. 'Visible Women in the Needle Trades: Revisiting the Clothing Industry in the Late Nineteenth and Early Twentieth Centuries.' In Becoming Visible: Women's Presence in Late Nineteenth-Century America, edited by Janet Floyd, 63-79. Amsterdam/New York: Rodopi. 